\title{
Quantification of Agricultural Mechanization Status for Etawah District of Uttar Pradesh, India
}

\author{
Tarun Kumar Maheshwari* and Ashok Tripathi
}

Farm Machinery and Power Engineering, VSAET, Sam Higginbottom University of Agriculture, Technology and Sciences (SHUATS), Allahabad-211 007, UP, India

*Corresponding author

\section{Keywords \\ Mechanization index, Power Availability, Total energy, Mechanical Energy Cropping Intensity \\ Article Info \\ Accepted: \\ 10 April 2019 \\ Available Online: \\ 10 May 2019}

\section{A B S T R A C T}

District Etawah falls in western part of Uttar Pradesh. The district has 8 blocks and 696 villages. The net sown area of the district is 1.48 lakh ha with cropping intensity of $210 \%$. Normal annual rainfall of the district is $792 \mathrm{~mm}$. Three main levels of mechanization technologies need consideration: human power, animal power and mechanical power technologies, with varying degrees of sophistication within each level, on the basis of capacity to do work, costs, precision and effectiveness. After selection of variables, a questionnaire was prepared to collect primary data from Etawah district of Uttar Pradesh. A Stratified Multistage Sampling Design was applied considering district and blocks as strata. The villages were selected from each block of Etawah district using random sampling and 4 blocks out of 8 blocks of Etawah district were taken for the study. Then from each blocks, villages and then from each villages, 15 farmers were selected using random sampling. Primary data were collected from 600 farmers from 40 villages. The Mechanization index, Power availability, Total energy, Mechanical energy, Human energy is highest in Basrehar block significantly in comparison to other three blocks ie 0.953 , $1.877 \mathrm{~kW} / \mathrm{ha}, 1990.32 \mathrm{kWh} / \mathrm{ha}, 1930.57 \mathrm{kWh} / \mathrm{ha}, 59.59 \mathrm{kWh} / \mathrm{ha}$,. The average value of Mechanization index, Power availability, Total energy, Mechanical energy, Human energy, cropping intensity, Irrigation intensity, farmers income and input cost in Etawah district is $0.9416,1.53 \mathrm{~kW} / \mathrm{ha}, 1250.59 \mathrm{kWh} / \mathrm{ha}, 1199.73 \mathrm{kWh} / \mathrm{ha}, 50.95 \mathrm{kWh} / \mathrm{ha}, 210 \%$, $799.84 \%$, Rs.143885 and Rs. 53729 respectively.

\section{Introduction}

District Etawah falls in western part of Uttar Pradesh and is surrounded by Mainpuri, Agra, Auraiya and state Madhya Pradesh. The district has 8 blocks and 696 villages. The total area of the district is 2434 square $\mathrm{km}$, supporting a population of 15.82 lakh with population densely as 684 persons per square $\mathrm{km}$. The district is endowed with Chambal and Yamuna rivers. The net sown area of the district is 1.48 lakh ha with cropping intensity of $155 \%$. Normal annual rainfall of the district is $792 \mathrm{~mm}$. More than $74 \%$ of the net sown area is irrigated and over $69 \%$ land is cultivated. The net irrigated area of the district is 1.34 lakh ha. The climate is semiarid arid the soil type is alluvium calcareous clay. 
In modern era, agricultural mechanization draws a major controversy that it is considered as the application of mechanical power technology, particularly tractors. However, three main levels of mechanization technologies need consideration: human power, animal power and mechanical power technologies, with varying degrees of sophistication within each level (Rijk, 1989), on the basis of capacity to do work, costs, and precision and effectiveness (Morris, 1985). Agricultural mechanization technology further varies from location to location and crop to crop. Thus the quality of inputs of mechanization, and consequently land and labour productivity may differ considerably (Gifford and Rijk, 1980). So, mechanization planning requires the quantification of level of mechanization for each crop production. Several authors developed different methods to quantify the level of mechanization based on power or energy availability, and its impact in agricultural and labour productivity.

Zangeneh et al., (2010) defined Mechanization Index (MI) and Level of Mechanization (LOM), to characterize farming system of potato in the Hamadan province of Iran. These indicators are defined mathematically as equations (1) and (2) respectively. The MI elaborated here is an expression of the deviation of the actual amount of motorized farm work from the normal values at the regional level.

$$
M I=\frac{1}{n} \sum_{i=1}^{n} \frac{M_{g(i)}}{M_{a v}} * \frac{L_{i}}{T L_{i}}
$$

Where,

MI = Mechanization Index for the production unit 'a',

Me (i) = Overall input energy due to machinery in the production unit 'a', Mav = Regional-average energy due to machinery,
$\mathrm{Li}=$ Land area cultivated in the production unit 'a',

$\mathrm{TLi}=$ Total farm land ownership of production unit 'a', $\mathrm{n}=$ Number of farms.

The MI index, proposed by Andrade and Jenkins, 2003 is an indication of the amount of machinery a given farmer uses for farm work compared with the average in the region. The second term in Equation (1) includes a ratio between the land area cultivated with soybean crop and the total land ownership. This term was introduced because it reflects the importance of land demand for cultivation. The LOM index is based on the premise that a mechanized farmer is the one that finds a way to utilize amounts of mechanical energy that are higher than the typical values using locally available technology.

$$
\operatorname{LOM}=\sum_{i=1}^{n} \frac{P_{i} * \eta}{L_{i}}
$$

Where, $\mathrm{LOM}=$ level of mechanization, $\mathrm{Pi}=$ power of tractors, $\eta=$ correction factor for utilized power $(0.75)$.

Field capacity was multiplied by rated power so the quantification of energy expenditure was made in work units $(\mathrm{kWh})$. The regional normal will be obtained after compiling a full dataset of all respondents and then it would be defined the mode for the number of passes for each operation as well as the mode in tractor size and field capacity.

The level of mechanization is calculated by the following formula (Almasi et al., 2000).

Mechanization level

$(\boldsymbol{h p} / \boldsymbol{h a})=\frac{\text { Total Power }}{\text { Cultivated Area }}$

The Total power of existing tractors $(\mathrm{hp})=$ Average nominal power of one tractor $\mathrm{x}$ Number of working tractors. 
Total real power of tractors $=$ Total power of existing tractors $\mathrm{x}$ Conversion coefficient (0.75).

Animal energy $(\mathrm{hp}-\mathrm{h})=$ Total existing animal power $x$ Annual functional hours.

Annual functional hours $=$ Number of functional days $\mathrm{x}$ Mean functional hours during a day.

Total existing animal power $(\mathrm{hp})=$ Produced power of animal x Number of animals.

Human energy (hp-h) can also be calculated in the same manner.

\section{Materials and Methods}

After selection of variables, a questionnaire was prepared to collect primary data from Etawah district of Uttar Pradesh. A Stratified Multistage Sampling Design was applied considering district and blocks as strata. The villages were selected from each block of Etawah district using random sampling and 4 blocks out of 8 blocks of Etawah district were taken for the study. Then from each blocks, villages and then from each villages, 15 farmers were selected using random sampling. Primary data were collected from 600 farmers from 40 villages. As mechanization is a multi-dimensional concept, thus the following indices were evaluated to study the mechanization status in target region.

To study the mechanization status of Etawah district of Uttar Pradesh, many variables were selected based on requirements to estimate degree of mechanization, level of mechanization (Power availability), mechanization index, cropping intensity, irrigation intensity, input cost and farmers income. The following variables were selected:

\section{Degree of mechanization (MD)}

It is one of the quantitative measure of mechanization, by which the degree of mechanization of different operations in a cropping system like land preparation, sowing, weeding, irrigation, spraying, harvesting, threshing, transportation of agricultural produce and etc. can be assessed. It is the ratio of mechanization area accomplished to the area to be mechanized (Almasi et al., 2000). The degree of mechanization of particular implements used in a particular agricultural operation can be given as:

Degree of Mechanization =Mechanized area/ Area to be Mechanized.

In other words, the degree of mechanization can be used to evaluate the extent of different agricultural operations performed using machinery or improved implements to the operations performed by humans, animals or traditional implement ie Area under bullocks, cultivator, power tiller, disc plough, M B plough, deshi hal (local plough), seed cum fertilizer drill, diesel engine, electric pump, sprinkler, dripper, sprayer (manually operated), sprayer (tractor operated), manual harvesting, thresher and combine harvester.

\section{Level of mechanization (power availability)}

Farm power is an essential input in agricultural production system to operate different types of equipment for timely field completion of agricultural works to increase productivity and maintain sustainability of farm. The mobile power is used for different field jobs like land preparation, sowing, weeding, spraying, and harvesting etc., whereas stationary power is used for lifting water, operating irrigation equipment, threshing, cleaning and grading of agricultural produce. The main sources of mobile power are human, draught animal, tractors, power 
tiller and self-propelled machines (combines, dozers, reapers, sprayers and etc.) where as the source of stationary power is oil engines and electric motors. In this study, power availability was also evaluated for Etawah district of Uttar Pradesh. The main sources of mobile power were human, draught animal, tractors and combines whereas the sources of stationary power were oil engines, electric motors and threshers in the Etawah District. The power availability was evaluated using formula given by Eq. 5

Power availability $(\mathrm{hp} / \mathrm{ha})=$ Total Power/ Net Cultivated Area

Where,

Total power $=$ Total mobile power + Total stationary power

Net Cultivated Area $=$ Net Cultivated Area of Target Region Villages wise number of tractor, combine harvester, bullocks, agricultural workers, power tiller, diesel engines and electric pump

\section{Mechanization index (MI)}

Farm operation wise mechanization index is one of the quantitative measures of mechanization and it can be defined as per capita power in terms of hp per hectare for a particular region. Evaluation of operation wise mechanization index first then Farmers wise human power, animal power and machinery power availability like tractor, thresher, combine. In this study, a new approach to evaluate Mechanization Index was used to overcome the demerits in the previous methodology to evaluate Mechanization Index and is given below:

$$
\begin{gathered}
\text { MIi } \quad r s \\
=\quad\left(\sum \sum M^{p} j k \times M^{t} j k\right) /
\end{gathered}
$$

$$
\begin{aligned}
& j=1 k \\
& =1 \\
& s \\
& { } \quad{ }_{s}\left(M \times M_{j k}^{t}+H^{p}{ }_{j k} \times\right. \\
& L^{\Sigma} \quad \sum_{j k}^{p} \quad M_{j k}^{t}+ \\
& j=1 k= \\
& 1 \\
& \left.{ }_{A}^{p} j k \times A^{t} j k\right]
\end{aligned}
$$

\section{Where,}

$\mathrm{MI}_{\mathrm{i}}=$ Mechanization Index of ith farm

$\mathrm{M}_{\mathrm{jk}}^{\mathrm{p}}=$ Power of machine used in kth operation in jth crop (including stationary and movable)

$\mathbf{M}_{\mathrm{jk}}^{\mathrm{t}}=$ Time taken by machine to perform kth operation in jth crop $\mathrm{H}_{\mathrm{jk}}{ }_{\mathrm{j}}=$ Power of human used in kth operation in jth crop (including stationary and movable)

$\mathrm{H}_{\mathrm{jk}}^{\mathrm{t}}=$ Time taken by human to perform kth operation in jth crop

$\mathrm{A}^{\mathrm{p}}{ }_{\mathrm{jk}}=$ Power of animal used in kth operation in jth crop (including stationary and movable)

$\mathrm{A}_{\mathrm{jk}}^{\mathrm{t}}=$ Time taken by animal to perform kth operation in jth crop

$\mathrm{i}=1$ to $n$, where $n$ is number of farm $\mathrm{j}=1$ to $r$, where $r$ is number of crop cultivated in a calendar year

$k=1$ to $\mathrm{s}$, where $s$ is no of farm practices in $j$ th cro

\section{Results and Discussion}

The graphical representation of variation of Mechanization index, Power availability, Total energy, Human energy, Mechanical energy, Degree of mechanization, Cropping intensity, Irrigation intensity, Farmers income and Input cost in four blocks i.e. Mahewa, 
Saifai, Badpura, Basrehar are shown in figure from 1 to 13. The average value of above mentioned parameters are also given in Table 2. The several farm mechanization parameters and their variability among different blocks were also studied using one way ANOVA. It was observed that Mechanization index, Power availability and other parameters varied significantly among blocks (Table 1).

Table.1 ANOVA for mechanization parameters

\begin{tabular}{|l|l|l|l|l|l|l|}
\hline \multicolumn{1}{|c|}{ Source } & \multicolumn{1}{c|}{ DF } & \multicolumn{5}{|c|}{ p-values } \\
\hline Model & 3 & $\begin{array}{l}\text { Mechanization } \\
\text { Index }\end{array}$ & $\begin{array}{l}\text { Total } \\
\text { Energy } \\
(\mathrm{kWh} / \mathrm{ha})\end{array}$ & $\begin{array}{l}\text { Human } \\
\text { Energy } \\
(\mathrm{kWh} / \mathrm{ha})\end{array}$ & $\begin{array}{l}\text { Mechanical } \\
\text { Energy } \\
(\mathrm{kWh} / \mathrm{ha})\end{array}$ & $\begin{array}{l}\text { Power } \\
\text { availability } \\
(\mathrm{kW} / \mathrm{ha})\end{array}$ \\
\hline Error & 16 & 0.0067 & 0.0050 & 0.0474 & 0.0056 & 0.0241 \\
\hline Total & 19 & & & & & \\
\hline $\mathbf{R}^{2}$ & - & 0.258 & 0.541 & 0.382 & 0.534709 & 0.248 \\
\hline CV & - & 1.668 & 47.120 & 38.18 & 48.81804 & 62.031 \\
\hline
\end{tabular}

Table.2 Comparison of mechanization parameters

\begin{tabular}{|c|c|c|c|c|c|}
\hline \multirow[t]{2}{*}{ Parameters } & \multicolumn{4}{|c|}{ Block } & LSD \\
\hline & Mahewa & Basrehar & Badpura & Saifai & - \\
\hline Mechanization Index & $0.9416 c$ & $0.9535 \mathrm{a}$ & $0.9378 \mathrm{~b}$ & $0.9333 b$ & 0.0285 \\
\hline Total Energy (kWh/ha) & $1164.25 b$ & $1990.32 \mathrm{a}$ & $987.49 \mathrm{c}$ & $860.70 \mathrm{~d}$ & 1042.7 \\
\hline $\begin{array}{l}\text { Human Energy } \\
(\mathrm{kWh} / \mathrm{ha})\end{array}$ & $43.46 \mathrm{c}$ & $59.59 \mathrm{a}$ & $50.24 b$ & $50.53 \mathrm{~b}$ & 33.969 \\
\hline $\begin{array}{l}\text { Mechanical Energy } \\
(\mathrm{kWh} / \mathrm{ha})\end{array}$ & $1120.80 \mathrm{~b}$ & $1930.73 a$ & $937.25 c$ & $810.17 d$ & 1036.8 \\
\hline $\begin{array}{l}\text { Power availability } \\
\text { (kW/ha) }\end{array}$ & $1.1184 \mathrm{~d}$ & $1.8777 \mathrm{a}$ & $1.5945 b$ & $1.5248 \mathrm{~b}$ & 1.7793 \\
\hline
\end{tabular}

Fig.1-13
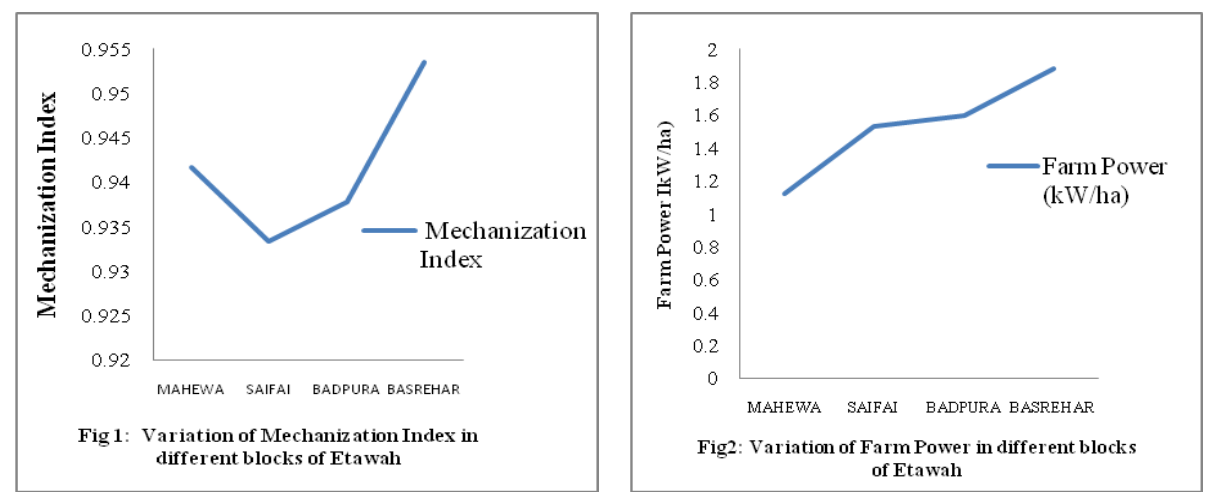
Int.J.Curr.Microbiol.App.Sci (2019) 8(5): 659-666
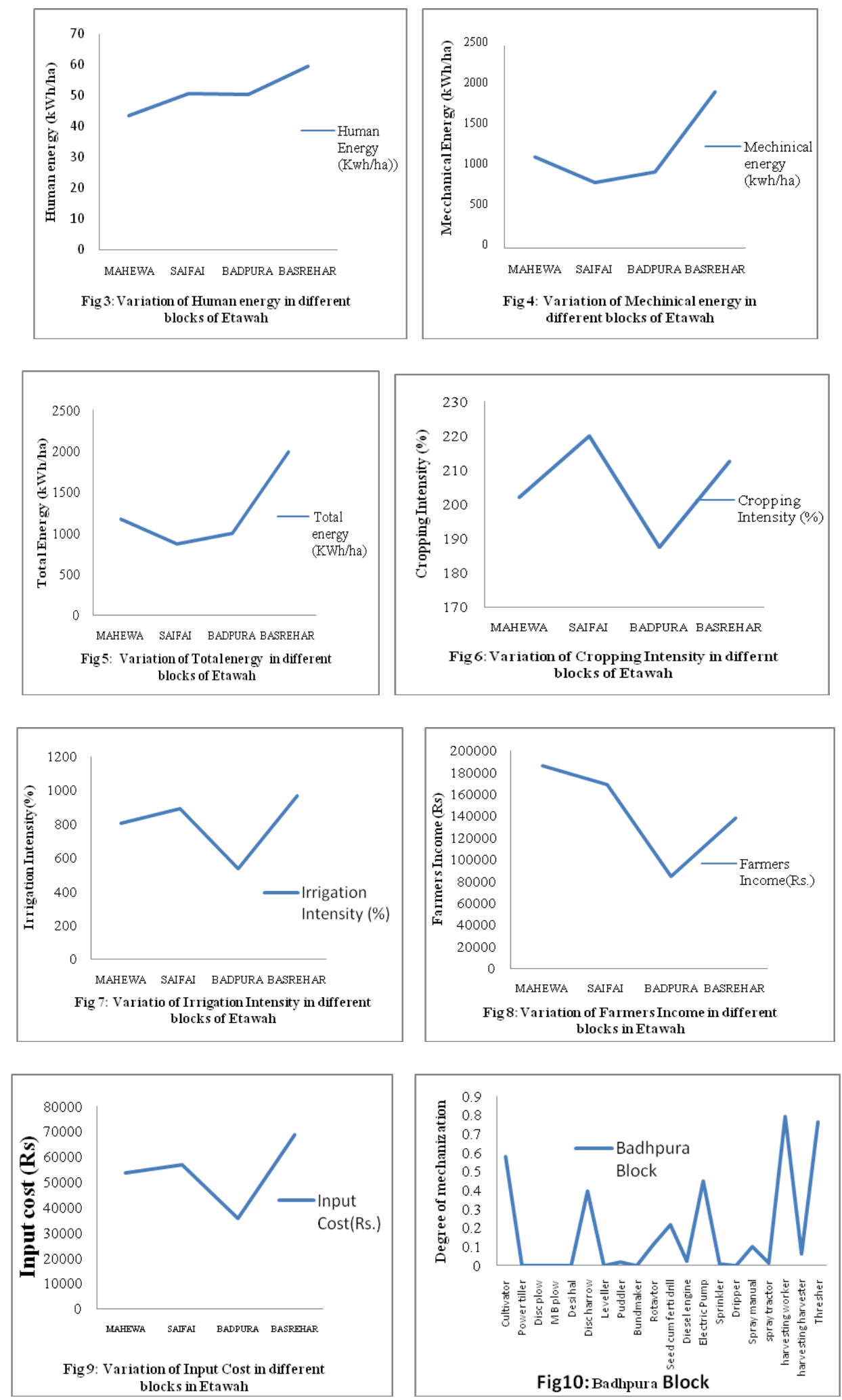

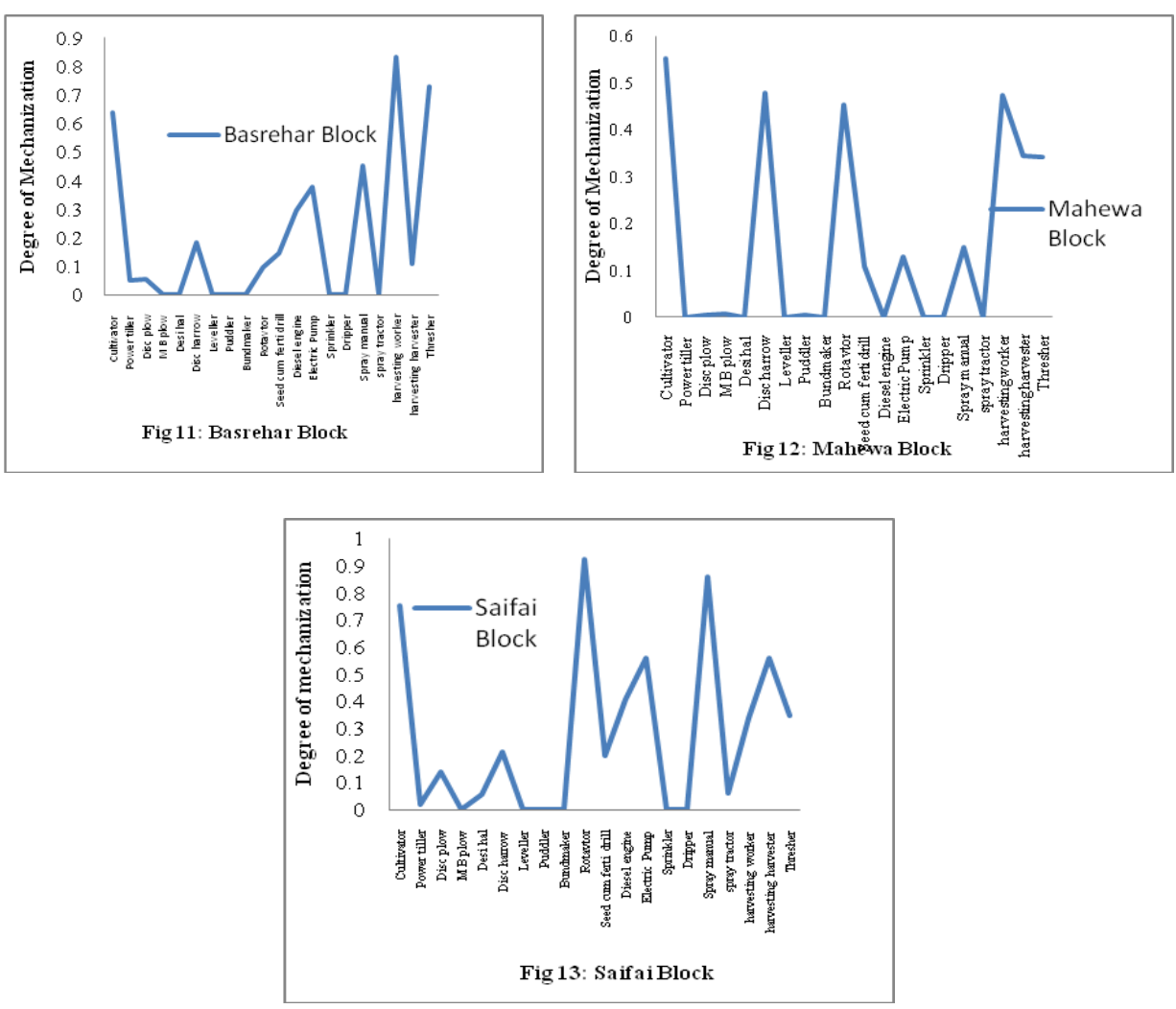

The comparisons of parameters for different blocks has been performed using LSD values and presented in (Table 2). It can be seen that Mechanization index, Power availability Total energy, Human energy and Mechanical energy varied significantly in different across blocks (Table 2).

In conclusion, the Mechanization Index, Power availability, Total energy, Mechanical energy, Human energy is highest in Basrehar block significantly in comparison to other three blocks as mentioned in above Table 2 . Buts the Badpura and Saifai have almost same insignificant value Mechanization Index and Power availability. The average value of Mechanization Index, Power availability, Total energy, Mechanical energy, Human energy, cropping intensity, Irrigation intensity, farmers income and input cost in Etawah district is $0.9416,1.53 \mathrm{~kW} / \mathrm{ha}$, $1250.59 \mathrm{kWh} / \mathrm{ha}, 1199.73 \mathrm{kWh} / \mathrm{ha}, 50.95$ kWh/ha, 210, 799.84, Rs.143885 and Rs. 53729 respectively.

\section{References}

Anonymous. 2018. Agriculture Census 201516 (Phase I) Provisional Results, Department of Agriculture, Cooperation and Farmers Welfare, Government of India (GOI). Report of Agriculture census 2015-16.

Anonymous, 2018. Annual Report 2017-18, Department of Agriculture, Cooperation and Farmers Welfare, Ministry of Agriculture and Farmers Welfare, Government of India, New Delhi, 93 p.

Roy Ramendu and Hasib Ahmad, 2015: State Agricultural Profile of Uttar Pradesh. Report of Agriculture profile 2014-15.

Almasi, M., S. Kiani, and N. Loui-mi. 2000. Principles of Agricultural Mechanization. Ma soumeh (PBUH) Publication. Ghom, Iran. PP. 19-40.

Gifford, R.C., and A.G. Rijik. 1980. Guidelines for Agricultural mechanization strategy in development. Economic and Social Commission for 
Asia and the Pa-cific (ESCAP), Regional Network for Agricultural machinery.

Morris, J., 1985. The economics of small farm mechanization. In 'Small Farm Mechanization for Developing Countries' (eds P. Crossley and Kilgour), pp. 171-184, John Wiley and Sons: New York.

Nowacki, T., 1978. Methodology used by ECE Countries in fore-casting mechanization developments. United Nations Economic Commission for Europe, AGRI/ MECH Report No. 74.

Nowacki, T., 1984. Changes and trends in the quantity and balance of energy consumption in agriculture (general methodology).

$\mathrm{FAO} /$

ECE/AGRI/MECH Report, No. 105, Geneva p. 36.

Andrade, P., and B. Jenkins. "Identification of Patterns of Farm Equipment Utilization in Two Agricultural Regions of Central and Northern Mexico". Agricultural Engineering International: the CIGR Journal of Scientific Re-search and Development. Invited Overview Paper.
Vol. V. June 2003.

Ramirez, A.A., A. Oida, H. Nakashi-ma, J. Miyasaka, and K. Ohdoi. 2007. Mechanization index and machinery energy ratio assessment by means of an Artificial Neural Network: A Mexican case study. Agricultural Engineering International. Manuscript PM 07002, 2.

Rijk, A. G. 1989. Agricultural mechanization policy and strategy- the case of Thailand. Asian Productivity Organization, Tokyo, Japan.

Singh, G., and D. De. 1999. Quantification of a mechanization indicator for Indian agriculture. Applied Engineering in Agriculture, 15(3): 197-204.

Singh, G., 2006. Estimation of a mechanization index and its impact on production and economic factors- A case study in India. Bio-systems Engineering, 93(1): 99-106

Zangeneh, M., M. Omid, and A. Akram. 2010. Assessment of agricultural mechanization status of potato production by means of Artificial Neural Network model. Australian Journal of Crop Science, 4(5): 372-377.

\section{How to cite this article:}

Tarun Kumar Maheshwari and Ashok Tripathi. 2019. Quantification of Agricultural Mechanization Status for Etawah District of Uttar Pradesh, India. Int.J.Curr.Microbiol.App.Sci. 8(05): 659-666. doi: https://doi.org/10.20546/ijcmas.2019.805.077 